\title{
Improve the Yield and Quality of Red Roomy and Thompson Seedless
} Grape Cultivars

\author{
Mohamed, A.K.A. ; Fatma El-Zahraa Mohamed; A. M. Gouda;
}

\author{
R. A. Ibrahim and Yassmin M. A. Madkor
}

Pomology Dept., Fac. Agric., Assiut Univ., Assiut, Egypt

*Email: aimanmohamed@hotmail.com

Received on: 9/8/2016

Accepted for publication on: 22/8/2016

\begin{abstract}
Experiments were carried out at the Experimental Orchard of Assiut University, Faculty of Agriculture. The experiments aimed to overcome the looseness of berries as well as improving the yield and berry quality of Red Roomy grape cultivar by using Boron, Zinc and NAA. The study also aimed to reduce the cluster compactness by using $\mathrm{GA}_{3}$ and cluster thinning in order to improve the quality of Thompson Seedless grape cultivar.

The treatments significantly increased the initial fruit set (IFS) and decreased the berry drop percentage. The cluster numbers not significantly affected by various treatments. However, the treatments increased the yield over the control. The control vines gave the lowest yield among all the treatments. The present study showed that there were no significant differences between treatments on the cluster width. On the other hand, treatments exhibited significant differences comparing with the control in respect of the cluster height. The treatments except of spraying with NAA had significant differences comparing with the control in respect of the cluster weight. However, the control vines gave the lowest cluster weight during the two studied seasons. On the contrary, the control gave the highest weight of 100 berries. On the other hand, although the control produced the highest juice weight of 100 berries but the differences were not significant during the two seasons of study. There were no significant differences between the treatments in respect of $\mathrm{TSS} \%$ during the two studied seasons. The sugar contents took the same trend of $\mathrm{TSS} \%$.
\end{abstract}

On the other hand, there were no significant differences between the treatments on the cluster number per vine of Thompson seedless grape cultivar. Yield weight significantly affected by $\mathrm{GA}_{3}$ application. The lowest yield obtained from the control. Data revealed that spraying the cluster with $\mathrm{GA}_{3}$ at $5+20+30 \mathrm{ppm}$ gave the highest values of cluster width $(\mathrm{cm})$ and height $(\mathrm{cm})$. The clusters treated with $\mathrm{GA}_{3}$ at $5+20+30$ ppm were the heaviest clusters among all the treatments and the differences between their values and the values of other treatments were significant during the two seasons of study. The weight of 100 berries and 100 berreis juice weight took the same trend of cluster weight. On the contrary of the previous results, the control and cluster thinning followed by $\mathrm{GA}_{3}$ at $5 \mathrm{ppm}+$ thinning had the highest $\mathrm{TSS} \%$ in the berry juice. Concerning the acidity percentage, the differences between the treatments mostly insignificant. $\mathrm{GA}_{3}$ application recorded also the least ratio of TSS/acid ratio, however, the other treatments significantly surpassed it in this respect. Cluster thinning gave 
the highest percentage of total sugars followed by $\mathrm{GA}_{3}$ at $5 \mathrm{ppm}+$ thinning and then the control.

This study concluded that the beneficial effects of spraying boron and zinc during flowering to increase the berry set and decrease berry drop of Red Roomy grape cultivar. On the other hand; Gibberellic acid $\left(\mathrm{GA}_{3}\right)$ spraying increased berry size, cluster weight and expand the cluster length of Thompson Seedless grape cultivar that suffering from cluster compactness. Cluster thinning can be used for increasing berry and cluster weight and improving the quality.

Keywords: Vitisvinefera, berry quality, GA, Thinning, Boron, Zinc.

\section{Introduction}

Grape is one of the most important fruit crops in the world not only for fresh consumption but also for raisins and juice making. Most of grape cultivars planted in Egypt belong to the table grape and all of them are European grape cultivars (Vitisvinifera L.).

In Egypt, grape occupy the second rank after citrus. According to the Ministry of Agriculture Statistics (2014), the total area devoted for grapes reached 192934 feddans including 171882 feddans as fruitful vines producing about 159169 tons with an average of 9.286 tons/feddan. In Upper Egypt, Assiut is the leading governorate for grape areas and producing.

During the last two decades, many grape cultivars have been introduced to Egypt. Most of these cultivars have been planted in the new reclaimed lands, however, old lands in middle and Upper Egypt are still planting in a large scale with Red Roomy and Thompson Seedless cultivars.

There are some problems encounter both cultivars. For Red Roomy, the looseness of berries is the serious problem while the common problem in Thompson Seedless is the cluster compactness.
Boron and zinc are considered as an essential elements for plant growth and development. Sexual reproduction in plant is more sensitive to low boron than the vegetative growth. It plays an important role in flowering and fruiting process, nitrogen metabolism biosynthesis and translocation of carbohydrates. While, zinc plays an important role in many biochemical reactions within the plants. Zinc is also regulates the activity of several enzymes. It also has a role in auxin production, formation of chlorophyll and carbohydrates and plays an important role in flowering and fruiting of the economic plants. (Subramoniam et al 2006; Song et al 2015)

On grape cultivars, both boron and zinc were extensively studied. Investigators agreed upon the effectiveness of these elements on berry set and yield [Onioue (1938), Ali (2000), Prabau and Singaram (2002), Subramoniam et al. (2006), Er et al (2011), and Song et al. (2015)]. On the other hand, it is known that NAA plays an important role for decreasing the fruit drop. It also found that, NAA improved physical and chemical properties of grapes (Abu-Zahra, 2013).

Gibberellic acid $\left(\mathrm{GA}_{3}\right)$ sprays are commonly used at bloom to increase berry size, cluster weight and 
expand the cluster length of the grape cultivars that suffering from cluster compactness such as Thompson Seedless grape cultivar [Hassan et al. (1988), Shaaban et al. (1989), Mansour (1994), Hussein et al. (1998), Abd-El-Ghanny (2000), Casanova et al. (2009), Rizk-Allaet al. (2011) and Mohsen (2015)].

Cluster thinning has been widely used for increasing berry and cluster weight and improving the quality. It applied alone or in combined with $\mathrm{GA}_{3}$ treatments (Mohsen, 2015; Zhao et al., 2006; Mohamed and Shaaban, 2008; Damotaet al., 2010 and Bogicevic et al. 2015).

The aims of this study were:

1- An attempt to overcome the looseness of berries as well as improving the yield and berry quality of Red Roomy grape cultivar by using Boron, Zinc and NAA,

2- Reduce the cluster compactness by using $\mathrm{GA}_{3}$ and cluster thinning to improve the quality of Thompson Seedless grape cultivar.

\section{Materials and Methods}

Experiments were carried out throughout two successive seasons of 2014 and 2015 on Red Roomy and Thompson Seedless grapevines grown at the Experimental Orchard of Assiut University, Faculty of Agriculture. The grapevines age were 12 years old at the beginning of the experiment and they were planted at $2 \times 2.5 \mathrm{~m}$ apart. Forty-five uniform grapevines from Red Roomy and twenty-eight grapevines from Thompson Seedless were chosen. All grapevines were pruned as the traditional training system with 20 fruit spurs and 4 buds were left on each spur for Red Roomy and 5 buds for
Thompson Seedless. Thus, the total buds left on each vine in this study were 80 and 100 buds for Red Roomy and Thompson Seedless grapevines, respectively.

The following procedures were executed on the vines:

\section{1) The First Experiment:}

This experiment was conducted on fourty five (45) Red Roomy grapevines. The treatment categories were:

1- Spraying with NAA at 2.5 ppm.

2- Spraying with NAA at 5 ppm.

3- Spraying with Boron at 20 ppm.

4- Spraying with Boron at 40 ppm.

5- Spraying with Zinc at 100 ppm.

6- Spraying with Zinc at 200 ppm.

7- Spraying with Boron at 20 $\mathrm{ppm}+$ Zinc at $100 \mathrm{ppm}$.

8- Spraying with Boron at 40 $\mathrm{ppm}+$ Zinc at $200 \mathrm{ppm}$.

9- Control (spraying with water).

The vines were sprayed using a Knapsack sprayer (16 L). A total volume of 16 lit was sufficient for spraying 5 vines. A surfactant super film at $0.1 \%$ was added to the spraying solutions. Both boron and zinc was used in chelated form. The spraying solution was added one time. The chelated elements were added during flowering period before the fall of caps while NAA was added after fruit set. Nine treatment combinations were tested comprised of NAA, Boron, and Zinc spraying 
along with a non-treated control. The experimental design was a completely randomized design with 5 replications and a vine was the experimental unit. Horticultural practices such as irrigation, soil management and fertilization were applied as recommended. The following measurements were taken on each vine:

1- Total number of clusters and yield weight $(\mathrm{kg})$.

2- Percentage of initial fruit set (IFS) was calculated according to Mohamed and El-Sese (2004). Two clusters from each vine which sprayed with Boron and Zinc were sacked with white cheesecloth sacks prior to fruit set by about 10 days. One month after fruit set, the clusters were detached from the vines with their sacks. In the laboratory, the clusters were drawn out from the sacks on white paper sheet and then they sacked off on it. The flowers and berries were divided into 1) normal berries. 2) dropped berries. 3) flowers that did not set. The percentage of initial fruit set was calculated according to the following equation:

$$
\text { IFS } \%=\frac{\text { Total No.berries/cluster }}{\text { Total No.flowers/cluster * }} \times 100
$$

Berry drop percentage was then calculated.

3- Five clusters from each vine yield were randomly taken to estimate the following parameters: (cm).

- Cluster width (cm) and height

- Cluster weight (g).

- 100 berries weight.

- 100 berries juice weight (g).

- Total soluble solids \% (TSS

$\%$ ) by using a hand refractometer.
- Total acidity using titration by $\mathrm{NaoH}$ at $0.1 \mathrm{~N}$ and phenolphthalein as an indicator then expressed as tartaric acid.

- TSS/acid ratio was then calculated.

- Total and reducing sugars according to Lane and Eynon procedure outlined in A.O.A.C. (1985).

\section{2) The second experiment:}

This experiment executed throughout two successive seasons of 2014 and 2015 on twenty eight (28) vines of Thompson Seedless grape cultivar.

The treatments were as follow:

1- Spraying with Gibberellic acid $\left(\mathrm{GA}_{3}\right)$ at $5 \mathrm{ppm}$ when the cluster reaches $8-10 \mathrm{~cm}$ long. This spraying aimed to expand the cluster. One month later (after fruit set), same vine were sprayed with $\mathrm{GA}_{3}$ at 20 ppm and then another spraying with 30 ppm after three weeks from the second spraying. The later 2 sprayings were to increase the berry size.

2- Hand cluster thinning by leaving the five shoulders located on the base of the cluster and removing the $6^{\text {th }}, 7^{\text {th }}$ and $8^{\text {th }}$ shoulders and then cutting the quarter of the cluster from the bottom.

3- Spraying with $\mathrm{GA}_{3}$ at $5 \mathrm{ppm}$ + cluster thinning.

4- Control.

The following parameters were estimated for each vine:

1- Total number of clusters and yield weight $(\mathrm{kg})$.

2- Cluster width $\mathrm{cm}$ ), cluster height $(\mathrm{cm})$, cluster weight $(\mathrm{g}), 100$ berries weight $(\mathrm{g})$ and 100 berries juice weight $(\mathrm{g})$. 
3- Total soluble solids $\%$, total acidity $\%$, TSS/acid ratio was then calculated, total sugars and reducing sugars.

The experiments were designed as a complete randomized design. The analysis of variance (ANOVA) was conducted according to Snedecor and Cochran (1972). Means were compared using the least significant differences (LSD) values at $5 \%$ level of the probability.

\section{Results and Discussion}

\section{I- The first experiment:}

The effect of boron and zinc spraying on initial fruit set percentage and berry drop of Red Roomy grape cultivar is presented in Table (1).

Data revealed that the treatments significantly increased the IFS with an exception of Boron at 20 ppm and Boron 40 ppm + Zinc 200 ppm. The most effective treatment in this respect was spraying with Zinc at $100 \mathrm{ppm}$ followed by Boron at 40 ppm and then Boron at $20 \mathrm{ppm}+$ Zinc at $100 \mathrm{ppm}$. The percentages related to the previous treatments were $23.43,19.40$ and $18.44 \%$ as an average of the two studied seasons, respectively. However, the percentage of IFS in the control was $12.90 \%$ (two season's average).

On the other hand, berry drop percentage (Table 1) was very high in the control as compared with the treatments. All the treatments showed high significant differences comparing with the control. Boron at 20 ppm exhibited the lowest berry drop percentage during the two studied seasons (9.44 and $9.79 \%$ for both seasons, respectively). While, Boron at $20 \mathrm{ppm}+$ Zinc at $100 \mathrm{ppm}$ was the $2^{\text {nd }}$ effective treatment in this respect followed by Zinc at $100 \mathrm{ppm}$. The percentage of berry drop for the last two treatments were 16.60 and $20.05 \%$ as an average of the two studied seasons, respectively. However, the control recorded the highest berry drop where it gave 46.28 and $48.27 \%$ for both seasons, respectively with an average of $47.27 \%$. 
Table 1. Effect of Boron and Zinc spraying on initial fruit set (IFS) and berry drop $\%$ of Red Roomy grape cultivar during 2014 and 2015 seasons.

\begin{tabular}{|l|c|c|c|c|c|c|}
\hline \multirow{2}{*}{ Treatment } & \multicolumn{3}{|c|}{ IFS \% } & \multicolumn{3}{c|}{ Berry drop \% } \\
\cline { 2 - 7 } Boron 20 ppm & $\mathbf{2 0 1 4}$ & $\mathbf{2 0 1 5}$ & Mean & $\mathbf{2 0 1 4}$ & $\mathbf{2 0 1 5}$ & Mean \\
\hline Boron 40 ppm & 15.50 & 13.64 & 14.57 & 09.44 & 09.79 & 09.62 \\
\hline Zinc 100 ppm & 19.62 & 19.19 & 19.40 & 22.12 & 27.37 & 24.75 \\
\hline Zinc 200 ppm & 25.22 & 21.64 & 23.43 & 16.32 & 23.78 & 20.05 \\
\hline Boron 20 ppm + zinc 100 ppm & 17.74 & 15.11 & 16.43 & 26.28 & 24.02 & 25.15 \\
\hline Boron 40 ppm + zinc 200 ppm & 19.45 & 17.43 & 18.44 & 14.28 & 18.92 & 16.60 \\
\hline Control & 14.64 & 13.75 & 14.20 & 18.25 & 19.99 & 19.12 \\
\hline L.S.D. 5\% & 13.68 & 12.12 & 12.90 & 46.48 & 48.27 & 47.27 \\
\hline
\end{tabular}

Yield components as affected by NAA, Boron and Zinc are found in Table 2 . The cluster numbers were not significantly affected by various treatments. The yield weight ( $\mathrm{kg} / \mathrm{vine})$ of Red Roomy grapevines subjected to the various treatments is presented in Table 2. The results revealed that spraying the vines with zinc at $100 \mathrm{ppm}$ produced the highest yield followed by boron at $20 \mathrm{ppm}+$ zinc at $100 \mathrm{ppm}$ along with Boron at $40 \mathrm{ppm}$. The yield weight ( $\mathrm{kg} / \mathrm{vine})$ associated with the previous treatments was 9.59, 9.50 and 9.17 $\mathrm{kg} / \mathrm{vine}$ as an average of two seasons, respectively. The rest of treatments, although they increased the yield over the control but the differences with the control were not significant. The control vines gave the lowest yield among all the treatments, $(7.88 \mathrm{~kg} /$ vine as an average of two seasons). The above- mentioned results were in accordance with these reported by Ali (2000), Farooq and Halmani (2000), Subramoniam et al. (2006), Krizsics and Diofasi (2007), Bybardi and Shabanov (2010), Ebrahim and ahmed (2012), Song et al. (2015). They found that spraying grapevine with Boron and/or Zinc greatly enhanced the fruit set and yield.

Boron influences favorably the germinability of pollen grains of grapevine and it probably acts as a special nutrition for generative growth upon the setting of berries of the cultivar because of the augmentation of the number and percentage of normal berries. On the other hand, zinc is required for the synthesis of auxins, chlorophyll and starch. The production of clusters with undeveloped berries and poor fruit set is due to zinc deficiency. 
Table 2. Effect of NAA, Boron and Zinc on yield components of Red Roomy grape cultivar during 2014 and 2015 seasons.

\begin{tabular}{|l|c|c|c|c|c|c|}
\hline \multirow{2}{*}{ Treatment } & \multicolumn{3}{c|}{ Cluster number } & \multicolumn{3}{c|}{ Yield weight (kg) } \\
\cline { 2 - 7 } NAA 2.5 ppm & $\mathbf{2 0 1 4}$ & $\mathbf{2 0 1 5}$ & Mean & $\mathbf{2 0 1 4}$ & $\mathbf{2 0 1 5}$ & Mean \\
\hline NAA 5 ppm & 22.80 & 24.40 & 23.60 & 8.00 & 8.74 & 8.37 \\
\hline Boron 20 ppm & 23.20 & 24.20 & 23.70 & 8.39 & 8.68 & 8.53 \\
\hline Boron 40 ppm & 22.40 & 23.80 & 23.10 & 8.33 & 8.77 & 8.55 \\
\hline Zinc 100 ppm & 24.60 & 25.80 & 25.20 & 9.20 & 9.14 & 9.17 \\
\hline Zinc 200 ppm & 23.20 & 23.60 & 23.40 & 9.76 & 9.42 & 9.59 \\
\hline Boron 20 ppm + Zinc 100 ppm & 23.00 & 24.00 & 23.50 & 8.42 & 8.91 & 8.67 \\
\hline Boron 40 ppm + Zinc 200 ppm & 22.20 & 23.60 & 22.90 & 8.19 & 8.70 & 8.45 \\
\hline Control & 22.80 & 23.80 & 23.30 & 7.93 & 7.83 & 7.88 \\
\hline L.S.D. 5\% & NS & NS & NS & 1.01 & 1.10 & 0.90 \\
\hline
\end{tabular}

The effect of NAA, Boron and Zinc on cluster dimensions is presented in Table 3. Data showed that there were no significant differences between treatments on the cluster width. On the other hand, treatments exhibited significant differences comparing with the control in respect of the cluster height. The highest value of cluster height was obtained from the vines treated with Boron at $20 \mathrm{ppm}$ and Boron at $40 \mathrm{ppm}$ with no significant differences between them. The average values of cluster height associated with these two treatments were 27.50 and 25.90 (cm) as an average of the two studied seasons, respectively. Spraying zinc at $100 \mathrm{ppm}$ in the $1^{\text {st }}$ season and Boron at $20 \mathrm{ppm}+$ zinc at $100 \mathrm{ppm}$ in the $2^{\text {nd }}$ season gave also significant differences comparing with the con- trol $(25.00$ and $26.00 \mathrm{~cm})$. The control vines gave the lowest value in this respect where the cluster height reached 20.60 (cm) (two season's average).

Data presented in Table (4) showed the effect of NAA, Boron and Zinc on cluster weight, 100 berries weight and 100 berries juice weight of Red Roomy grapevines.

The results revealed that the treatments except of spraying with NAA had significant differences comparing with the control in respect of the cluster weight. The treatments of zinc at $100 \mathrm{ppm}$, Boron at $20 \mathrm{ppm}$ + zinc at 100 ppm and Boron at 40 ppm gave the bet results and significantly surpassed the control. The average cluster weight over seasons reached 410.5, 399.5 and $396.8(\mathrm{~g})$ for the previous treatments, respec- 
tively. However, the control vines gave the lowest cluster weight during the two studied seasons (348.2 and $329.2 \mathrm{~g}$ ), respectively. On the contrary, the control gave the highest weight of 100 berries (Table 5). The 100 berries weight of the control was 508.0 and $497.8(\mathrm{~g})$ for the two sea- sons with an average of 502.9 (g). The lowest values in this respect were associated with the treatments of zinc at $100 \mathrm{ppm}$, Boron at $40 \mathrm{ppm}$ and Boron at $20 \mathrm{ppm}$. These treatments gave an average weight of 435.4, 441.3 and 451.1 (g), respectively.

Table 3. Effect of NAA, Boron and Zinc on cluster width and height of Red Roomy grape cultivar during 2014 and 2015 seasons.

\begin{tabular}{|l|c|c|c|c|c|c|}
\hline \multirow{2}{*}{ Treatment } & \multicolumn{3}{c|}{ Cluster width (cm) } & \multicolumn{3}{c|}{ Cluster height (cm) } \\
\cline { 2 - 7 } & $\mathbf{2 0 1 4}$ & $\mathbf{2 0 1 5}$ & Mean & $\mathbf{2 0 1 4}$ & $\mathbf{2 0 1 5}$ & Mean \\
\hline NAA 2.5 ppm & 13.00 & 15.20 & 14.10 & 23.60 & 21.00 & 22.30 \\
\hline NAA 5 ppm & 12.00 & 15.60 & 13.80 & 20.60 & 24.40 & 22.50 \\
\hline Boron 20 ppm & 14.20 & 16.00 & 15.10 & 25.40 & 26.40 & 25.90 \\
\hline Boron 40 ppm & 13.60 & 15.40 & 14.50 & 26.20 & 28.80 & 27.50 \\
\hline Zinc 100 ppm & 14.00 & 14.40 & 14.20 & 25.00 & 22.20 & 23.60 \\
\hline Zinc 200 ppm & 13.40 & 12.60 & 13.00 & 20.00 & 23.60 & 21.80 \\
\hline Boron 20 ppm + Zinc 100 ppm & 13.80 & 14.60 & 14.20 & 23.20 & 26.00 & 24.60 \\
\hline Boron 40 ppm + Zinc 200 ppm & 12.00 & 12.80 & 12.40 & 20.20 & 22.00 & 21.10 \\
\hline Control & 12.60 & 12.80 & 12.70 & 19.20 & 22.00 & 20.60 \\
\hline L.S.D. 5\% & NS & NS & NS & 04.52 & 03.51 & 02.80 \\
\hline
\end{tabular}


Table 4. Effect of NAA, Boron and Zinc on weight (g) of cluster; 100 berries and 100 berries juice of Red Roomy grape cultivar during 2014 and 2015 seasons.

\begin{tabular}{|l|c|c|c|c|c|c|c|c|c|}
\hline \multirow{2}{*}{ Treatment } & \multicolumn{3}{|c}{ Cluster weight } & \multicolumn{3}{c|}{ 100 berries weight } & \multicolumn{3}{c|}{ 100 berries juice weight } \\
\cline { 2 - 9 } & $\mathbf{2 0 1 4}$ & $\mathbf{2 0 1 5}$ & Mean & $\mathbf{2 0 1 4}$ & $\mathbf{2 0 1 5}$ & Mean & $\mathbf{2 0 1 4}$ & $\mathbf{2 0 1 5}$ & Mean \\
\hline NAA 2.5 ppm & 351.0 & 355.0 & 353.0 & 473.9 & 469.4 & 471.7 & 280.2 & 277.8 & 279.0 \\
\hline NAA 5 ppm & 360.2 & 359.2 & 359.7 & 465.1 & 449.7 & 457.4 & 265.6 & 260.6 & 263.1 \\
\hline Boron 20 ppm & 372.6 & 365.6 & 369.1 & 449.9 & 452.4 & 451.1 & 263.0 & 272.4 & 267.7 \\
\hline Boron 40 ppm & 410.8 & 382.8 & 396.8 & 435.6 & 447.0 & 441.3 & 269.6 & 268.0 & 268.8 \\
\hline Zinc 100 ppm & 421.8 & 399.2 & 410.5 & 416.9 & 453.8 & 435.4 & 248.0 & 267.0 & 257.5 \\
\hline Zinc 200 ppm & 368.6 & 367.4 & 368.0 & 449.4 & 464.7 & 457.0 & 276.0 & 276.4 & 276.2 \\
\hline $\begin{array}{l}\text { Boron 20 ppm } \\
\text { Zinc 100 ppm }\end{array}$ & 405.2 & 393.8 & 399.5 & 458.6 & 461.4 & 460.0 & 274.8 & 274.0 & 274.4 \\
\hline $\begin{array}{l}\text { Boron 40 ppm } \\
\text { Zinc 200 ppm }\end{array}$ & 369.0 & 367.6 & 368.3 & 449.3 & 459.8 & 454.5 & 270.8 & 274.2 & 272.5 \\
\hline Control & 348.2 & 329.2 & 338.7 & 508.0 & 497.8 & 502.9 & 299.6 & 298.6 & 299.1 \\
\hline L.S.D. 5\% & 048.1 & 035.2 & 027.2 & 039.4 & NS & 028.1 & NS & NS & NS \\
\hline
\end{tabular}

On the other hand, although the control produced the highest juice weight of 100 berries (Table 4) but the differences were not significant during the two seasons of study.

These results came on line with the other papers reported by Ali (2000), Farooq and Hulmani (2000), Subramoniam et al. (2006), Ebrahim and Ahmed (2012), Abou Zahra (2013), Nikkah et al. (2013) and Mohsen (2015). They found that spraying the grapevines with Boron and/or Zinc increased cluster weight, berry weight and size. Boron plays an important role of both cell division and enlargement. On the other hand, zinc is required to obtain an optimum crop growth.

On the other hand, Kamal (2006) found that spraying Thomp- son Seedless grape cultivar with NAA at $10 \mathrm{ppm}$ decreased berry weight and volume and decreased berry drop.

The effect of various treatments on some chemical characteristics of Red Roomy grape cultivar is presented in Tables 5 and 6.

There were no significant differences between the treatments in respect of $\mathrm{TSS} \%$ (Table 5) during the two studied seasons, however, the combined analysis over seasons exhibited significant differences where the control surpassed most of the treatments $(17.10 \%)$. The lowest percentages of TSS were obtained from zinc at $100 \mathrm{ppm}$ and Boron at $40 \mathrm{ppm}$ (15.70 and $15.90 \%$, respectively). 
The titratable acidity of various treatments revealed that the highest percentage of acidity was obtained from NAA at $2.5 \%$ and then the control along with Boron at $40 \mathrm{ppm}+$ Zinc at $200 \mathrm{ppm}$. The later treatments gave $0.390,0.382$ and $0.374 \%$, respectively, as an average of the two seasons of study. While, the lowest acidity percentage was obtained from Boron at $40 \mathrm{ppm}$ and Boron at $20 \mathrm{ppm}(0.305$ and $0.345 \%$, respectively). The differences were significant during the two seasons and over seasons.
Concerning the values of TSS/acidity, the presented results (Table 5) revealed that spraying with Boron at 40 ppm significantly surpassed most of the other treatments. The ratio of this treatment reached 53.27, while Boron at $40 \mathrm{ppm}+$ Zinc at $200 \mathrm{ppm}$ and NAA at $2.5 \mathrm{ppm}$ gave the lowest ratios (43.27 and 42.79, respectively). Boron at 20 ppm gave also a higher ratio (47.07) but the difference between it and the control (44.99) was not significant.

Table 5. Effect of NAA, Boron and Zinc on TSS; acidity and TSS/acid ratio of Red Roomy grape cultivar during 2014 and 2015 seasons.

\begin{tabular}{|l|c|c|c|c|c|c|c|c|c|}
\hline \multirow{2}{*}{ Treatment } & \multicolumn{3}{|c|}{ TSS \% } & \multicolumn{3}{c|}{ Acidity \% } & \multicolumn{3}{c|}{ TSS/Acid Ratio } \\
\cline { 2 - 9 } & $\mathbf{2 0 1 4}$ & $\mathbf{2 0 1 5}$ & Mean & $\mathbf{2 0 1 4}$ & $\mathbf{2 0 1 5}$ & Mean & $\mathbf{2 0 1 4}$ & $\mathbf{2 0 1 5}$ & Mean \\
\hline NAA 2.5 ppm & 16.4 & 16.8 & 16.60 & 0.405 & 0.375 & 0.390 & 40.59 & 44.99 & 42.79 \\
\hline NAA 5 ppm & 16.2 & 16.2 & 16.20 & 0.386 & 0.353 & 0.369 & 42.08 & 45.98 & 44.03 \\
\hline Boron 20 ppm & 16.0 & 16.4 & 16.20 & 0.360 & 0.330 & 0.345 & 44.48 & 49.66 & 47.07 \\
\hline Boron 40 ppm & 15.6 & 16.2 & 15.90 & 0.265 & 0.345 & 0.305 & 59.64 & 46.90 & 53.27 \\
\hline Zinc 100 ppm & 15.4 & 16.0 & 15.70 & 0.381 & 0.336 & 0.359 & 40.41 & 47.65 & 44.03 \\
\hline Zinc 200 ppm & 16.0 & 16.8 & 16.40 & 0.376 & 0.359 & 0.368 & 42.53 & 46.83 & 44.68 \\
\hline Boron 20 ppm + Zinc 100 ppm & 16.0 & 16.8 & 16.40 & 0.380 & 0.338 & 0.359 & 42.14 & 49.82 & 45.98 \\
\hline Boron 40 ppm + Zinc 200 ppm & 15.8 & 16.4 & 16.10 & 0.395 & 0.353 & 0.374 & 40.00 & 46.54 & 43.27 \\
\hline Control & 17.0 & 17.2 & 17.10 & 0.383 & 0.381 & 0.382 & 44.49 & 45.49 & 44.99 \\
\hline L.S.D. 5\% & NS & NS & 0.75 & 0.023 & 0.023 & 0.020 & 04.49 & NS & 02.99 \\
\hline
\end{tabular}

The sugar contents took the same trend of TSS\% where the control gave the highest values of total sugars. Data presented in Table 6 showed that there were significant differences between the control and all the other treatments (except of NAA at $2.5 \mathrm{ppm}$ in 2014). The per- centage of total sugar in the control was $16.10 \%$ (2 seasons average) while the least percentages were taken from Boron at $40 \mathrm{ppm}$, followed by Zinc at $100 \mathrm{ppm}$ and then Boron at $20 \mathrm{ppm}$.

The average of total sugars percentage for the later treatments was 
$14.65,14.69$ and $14.97 \%$, respectively. The reducing sugars percentages took the same trend of total sugars where the control surpassed all other treatments, but the differences were significant only in the $1^{\text {st }}$ season of study. Most of treatments produced berries containing more non-reducing sugars as comparing with the control, however, the differences were not significant.

Table 6. Effect of NAA, Boron and Zinc on sugar contents of Red Roomy grape cultivar during 2014 and 2015 seasons.

\begin{tabular}{|l|c|c|c|c|c|c|c|c|c|}
\hline \multirow{2}{*}{ Treatment } & \multicolumn{2}{|c|}{ Total sugars \% } & \multicolumn{3}{c|}{ Reducing sugars \% } & \multicolumn{3}{c|}{ Non-reducing sugars \% } \\
\cline { 2 - 10 } & 15.27 & 15.12 & 15.20 & 14.58 & 14.55 & 14.57 & 0.69 & 0.57 & 0.63 \\
\hline NAA 2.5 ppm & 15.17 & 14.93 & 15.05 & 14.60 & 14.41 & 14.51 & 0.57 & 0.51 & 0.54 \\
\hline NAA 5 ppm & 14.84 & 15.11 & 14.97 & 14.25 & 14.58 & 14.42 & 0.59 & 0.53 & 0.56 \\
\hline Boron 20 ppm & 14.54 & 14.77 & 14.65 & 13.94 & 14.30 & 14.02 & 0.60 & 0.47 & 0.54 \\
\hline Boron 40 ppm & 14.78 & 14.59 & 14.69 & 14.33 & 13.98 & 14.16 & 0.44 & 0.61 & 0.53 \\
\hline Zinc 100 ppm & 14.98 & 15.25 & 15.12 & 14.37 & 14.66 & 14.41 & 0.61 & 0.58 & 0.60 \\
\hline Zinc 200 ppm & 14.84 & 15.27 & 15.06 & 14.26 & 14.76 & 14.51 & 0.58 & 0.51 & 0.54 \\
\hline Boron 20 ppm + Zinc 100 ppm & 14.90 & 15.26 & 15.08 & 14.25 & 14.78 & 14.52 & 0.45 & 0.48 & 0.46 \\
\hline Boron 40 ppm + Zinc 200 ppm & 16.03 & 16.16 & 16.10 & 15.58 & 15.71 & 15.64 & 0.45 & 0.48 & 0.46 \\
\hline Control & 0.79 & 0.81 & 0.57 & 0.84 & NS & NS & NS & NS & NS \\
\hline L.S.D. 5\% & & & & & &
\end{tabular}

Some investigators reported that treating the grapevines with Boron and Zinc either had no effect on berry quality or decreased it but the berry reached its maturity standards. Christensen and Jensen (1978) mentioned that dilute application of zinc caused larger berries and lower Brix. They explained that the lower Brix readings are the result of increased berry set from zinc treatment response. Also, Krizsics and Diofasi (2007) found a positive correlation between boron concentrations of the leaves and the titratable acidity.

On the other hand, investigators found that applying Boron and Zinc to the grapevines improved berry quality in terms of TSS, acidity and sugars, e.g. Abdel-Hady (1995), Radwan (1999), Ali (2000), Prabu and Singaram (2002), Subramonicam et al. (2006), Bybordi and Shabanov (2010), Risk-Alla et al. (2011), Ebrahim and Ahmed (2012) and Song et al. (2015).

\section{II- The second experiment:}

The effect of $\mathrm{GA}_{3}$ spraying and cluster thinning on yield and quality of Thompson Seedless grape cultivar is presented in Tables 7-11.

Table 7 shows the results of yield components during the two studied seasons as affected by vari- 
ous treatments. The second season of study gave much higher yield in terms of cluster numbers or weight comparing with the first season. There were no significant differences between the treatments on the cluster number per vine. The vines gave around 19.00 and 44.00 clusters/vine during the $1^{\text {st }}$ and $2^{\text {nd }}$ seasons, respectively. Yield weight (Table 7) significantly affected by $\mathrm{GA}_{3}$ application. Spraying with $\mathrm{GA}_{3}$ at $5+20$ +30 ppm significantly improved the yield weight comparing with the other treatments. Such treatment produced 7.27 and $19.43 \mathrm{~kg} /$ vine in the two seasons, respectively with an average of $13.35 \mathrm{~kg} /$ vine. The lowest yield was obtained from the control which gave 5.63 and $15.14 \mathrm{~kg} /$ vine for the two studied seasons, respectively with an average of 10.39 $\mathrm{kg} /$ vine. The differences between thinning, $\mathrm{GA}_{3}+$ thinning and the control were not significant during the two seasons or over seasons.

The effect of $\mathrm{GA}_{3}$ and cluster thinning on cluster dimensions is presented in Table 8 .
Data revealed that, spraying the cluster with $\mathrm{GA}_{3}$ at $5+20+30 \mathrm{ppm}$ gave the highest values of cluster width $(\mathrm{cm})$ and height $(\mathrm{cm})$. The clusters subjected to such treatment exhibited significant differences (except of the $1^{\text {st }}$ season) comparing with the other treatments. The mean cluster width $(\mathrm{cm})$ reached $17.57 \mathrm{~cm}$ (two seasons average) for this treatment, however, the differences between other treatments were not significant during both seasons of study. Concerning the cluster height $(\mathrm{cm})$, the results showed that spraying with $\mathrm{GA}_{3}$ at $5+20+30 \mathrm{ppm}$ significantly surpassed the rest of treatments. The values associated with such treatment reached 26.29 and $30.57 \mathrm{~cm}$ for the two studied seasons with an average of $28.43 \mathrm{~cm}$. Cluster thinning and $\mathrm{GA}_{3}$ at $5 \mathrm{ppm}+$ thinning gave values lesser than the control. The mean cluster height (cm) for the control was $25.21 \mathrm{~cm}$ (two season's average).

Table 7. Effect of $\mathrm{GA}_{3}$ and cluster thinning on yield components of Thompson Seedless grape cultivar during 2014 and 2015 seasons.

\begin{tabular}{|l|c|c|c|c|c|c|}
\hline \multirow{2}{*}{ Treatment } & \multicolumn{3}{|c|}{ Cluster number } & \multicolumn{3}{c|}{ Yield weight (kg) } \\
\cline { 2 - 7 } & $\mathbf{2 0 1 4}$ & $\mathbf{2 0 1 5}$ & Mean & $\mathbf{2 0 1 4}$ & $\mathbf{2 0 1 5}$ & Mean \\
\hline GA 3 5 + 20 + 30 ppm & 19.00 & 44.29 & 31.64 & 7.27 & 19.43 & 13.35 \\
\hline Thinning & 19.57 & 44.71 & 32.14 & 6.64 & 15.81 & 11.23 \\
\hline GA 5 ppm + Thinning & 18.57 & 45.29 & 31.93 & 6.26 & 16.16 & 11.21 \\
\hline Control & 19.71 & 44.43 & 32.07 & 5.63 & 15.14 & 10.39 \\
\hline L.S.D. 5\% & NS & NS & NS & 1.08 & 02.09 & 01.68 \\
\hline
\end{tabular}


Table 8. Effect of $\mathrm{GA}_{3}$ and cluster thinning on cluster width and height of Thompson Seedless grape cultivar during 2014 and 2015 seasons.

\begin{tabular}{|l|c|c|c|c|c|c|}
\hline \multirow{2}{*}{ Treatment } & \multicolumn{3}{|c|}{ Cluster width (gm) } & \multicolumn{3}{c|}{ Cluster height (cm) } \\
\cline { 2 - 7 } & $\mathbf{2 0 1 4}$ & $\mathbf{2 0 1 5}$ & Mean & $\mathbf{2 0 1 4}$ & $\mathbf{2 0 1 5}$ & Mean \\
\hline GA $_{\mathbf{3}} \mathbf{5}+\mathbf{2 0}+\mathbf{3 0} \mathbf{~ p p m}$ & 16.14 & 19.00 & 17.57 & 26.29 & 30.57 & 28.43 \\
\hline Thinning & 15.43 & 17.43 & 16.43 & 19.57 & 24.71 & 22.14 \\
\hline GA $\mathbf{5} \mathbf{~ p p m}+$ Thinning & 15.57 & 17.71 & 16.64 & 20.29 & 24.14 & 22.21 \\
\hline Control & 14.57 & 16.71 & 15.64 & 23.71 & 26.71 & 25.21 \\
\hline L.S.D. 5\% & NS & 1.54 & 01.33 & 02.05 & 02.23 & 01.47 \\
\hline
\end{tabular}

Data of the cluster weight $(\mathrm{g})$, 100 berries weight (g) and 100 berries juice weight (g) which were subjected to various treatments are shown in Table 9.

The clusters treated with $\mathrm{GA}_{3}$ at $5+20+30$ ppm were the heaviest clusters among all the treatments and the differences between their values and the values of other treatments were significant during the two seasons of study.

The recorded values of cluster weight for such treatment were 385.1 and $441.4 \mathrm{~g}$ ) for the two seasons, respectively with an average of $413.3(\mathrm{~g})$. The second best treatment was $\mathrm{GA}_{3}$ at $5 \mathrm{ppm}+$ thinning. The later treatment had a significant differences with the control in the $1^{\text {st }}$ season of study and over the two seasons. The mean cluster weight of it reached 347.9 (g) while it was 312.5 (g) in the control (two season's average). Thinning alone also sur- passed the control respecting the cluster weight but the differences were not significant during the two studied seasons. The weight of 100 berries (Table 9) took the same trend of cluster weight. The superior treatment was $\mathrm{GA}_{3}$ at $5+2+30 \mathrm{ppm}$ followed by $\mathrm{GA}_{3}$ at $5 \mathrm{ppm}+$ thinning and then thinning alone. The differences between the three treatments and the control were significant. As an average of the two studied seasons, the 100 berries weight associated with these treatments was 189.7 , 152.1 and $134.4(\mathrm{~g})$, respectively, while it was $115.3(\mathrm{~g})$ in the control. Data presented in the same Table showed also that 100 berries juice weight significantly affected by $\mathrm{GA}_{3}$ at $5+20+30 \mathrm{ppm}$. The average 100 berries juice weight of this treatment was $78.57(\mathrm{~g})$. However, the differences between the other treatments were not significant during the two studied seasons. 
Table 9. Effect of $\mathrm{GA}_{3}$ and cluster thinning on weight (g) of cluster; 100 berries and 100 berries juice of Thompson Seedless grape cultivar during 2014 and 2015 seasons.

\begin{tabular}{|c|c|c|c|c|c|c|c|c|c|}
\hline \multirow[t]{2}{*}{ Treatment } & \multicolumn{3}{|c|}{$\begin{array}{c}\text { Cluster weight } \\
\text { (g) }\end{array}$} & \multicolumn{3}{|c|}{$\begin{array}{c}100 \text { berries weight } \\
\text { (g) }\end{array}$} & \multicolumn{3}{|c|}{$\begin{array}{l}100 \text { berries juice weight } \\
\text { (g) }\end{array}$} \\
\hline & 2014 & 2015 & Mean & 2014 & 2015 & Mean & 2014 & 2015 & Mean \\
\hline $\mathrm{GA}_{3} 5+20+30 \mathrm{ppm}$ & 385.1 & 441.4 & 413.3 & 185.5 & 193.9 & 189.7 & 77.57 & 79.57 & 78.57 \\
\hline Thinning & 318.9 & 354.6 & 336.7 & 128.4 & 140.4 & 134.4 & 64.71 & 64.43 & 64.57 \\
\hline $\mathrm{GA}_{3} 5 \mathrm{ppm}+$ Thinning & 337.7 & 358.0 & 347.9 & 136.0 & 168.2 & 152.1 & 68.29 & 64.86 & 66.57 \\
\hline Control & 285.9 & 339.1 & 312.5 & 113.4 & 117.2 & 115.3 & 62.71 & 62.00 & 62.36 \\
\hline L.S.D. 5\% & 36.53 & 36.80 & 25.06 & 07.48 & 10.40 & 06.2 & 09.95 & 10.32 & 06.93 \\
\hline
\end{tabular}

The results of berry quality as influenced by $\mathrm{GA}_{3}$ application and cluster thinning are presented in Tables 10 and 11 .

On the contrary of the previous results, the control and $\mathrm{GA}_{3}$ at $5 \mathrm{ppm}$ + thinning followed by cluster thinning had the highest TSS\% in the berry juice (Table 10). The differences between these three treatments and the $1^{\text {st }}$ treatment were significant, however, the differences between these three treatments were not significant. Concerning the acidity percentage, the differences between the treatments mostly insignificant except of the second season which $\mathrm{GA}_{3}$ at $5+20+30 \mathrm{ppm}$ and $\mathrm{GA}_{3}$ at $5 \mathrm{ppm}+$ thinning significantly increased the acidity \% compared with the other two treatments. GA application recorded also the least ratio of TSS/acidity (Table 10), however, the other treatments significantly surpassed it in this respect. The TSS/acid ratios were 23.24, $23.22,22.48$ and 20.43 for the con- trol, thinning, GA3 at $5 \mathrm{ppm}+$ thinning, and $\mathrm{GA}_{3}$ at $5+20+30 \mathrm{ppm}$ as an average of two seasons, respectively.

Data concerning the sugar contents are presented in Table 11. The results of sugars took the same trend of TSS\%. Cluster thinning gave the highest percentage of total sugars followed by $\mathrm{GA}_{3}$ at $5 \mathrm{ppm}+$ thinning and then the control, however, the differences between them were not significant. These three treatments significantly surpassed the treatment $\mathrm{GA}_{3}$ at $5+20+30$ ppm where it recorded the lowest percentage of total sugars $(19.11 \%)$. Same trend could be observed respecting the reducing sugars percentage where $\mathrm{GA}_{3}$ at $5+$ $20+30 \mathrm{ppm}$ gave the lowest values. On the other hand, the highest percentage of non-reducing sugars was found in the control $(0.64 \%)$ while the differences between the other treatments were not significant during the two studied seasons. 
Table 10. Effect of $\mathrm{GA}_{3}$ and cluster thinning on TSS; acidity and TSS/Acid ratio of Thompson Seedless grape cultivar during 2014 and 2015 seasons.

\begin{tabular}{|l|c|c|c|c|c|c|c|c|c|}
\hline \multirow{2}{*}{\multicolumn{1}{|c|}{ Treatment }} & \multicolumn{3}{|c|}{ TSS \% } & \multicolumn{3}{c|}{ Acidity \% } & \multicolumn{3}{c|}{ TSS/Acid ratio } \\
\cline { 2 - 10 } & $\mathbf{2 0 1 4}$ & $\mathbf{2 0 1 5}$ & Mean & $\mathbf{2 0 1 4}$ & $\mathbf{2 0 1 5}$ & Mean & $\mathbf{2 0 1 4}$ & $\mathbf{2 0 1 5}$ & Mean \\
\hline GA $_{\mathbf{3}} \mathbf{5}+\mathbf{2 0}+\mathbf{3 0} \mathbf{~ p p m}$ & 21.43 & 19.86 & 20.64 & 1.012 & 1.029 & 1.020 & 21.52 & 19.33 & 20.43 \\
\hline Thinning & 23.43 & 21.14 & 22.29 & 0.953 & 0.971 & 0.962 & 24.59 & 21.85 & 23.22 \\
\hline GA $3_{\mathbf{5}} \mathbf{5} \mathbf{~ p p m}+$ Thinning & 23.80 & 21.57 & 22.71 & 1.011 & 1.018 & 1.014 & 23.76 & 21.20 & 22.48 \\
\hline Control & 23.57 & 21.86 & 22.71 & 0.992 & 0.966 & 0.979 & 23.83 & 22.65 & 23.24 \\
\hline L.S.D. 5\% & 01.25 & 01.25 & 0.86 & NS & 0.040 & NS & NS & 01.66 & 01.52 \\
\hline
\end{tabular}

Table 11. Effect of $\mathrm{GA}_{3}$ and cluster thinning on sugar contents of Thompson Seedless grape cultivar during 2014 and 2015 seasons.

\begin{tabular}{|l|c|c|c|c|c|c|c|c|c|}
\hline \multirow{2}{*}{ Treatment } & \multicolumn{3}{|c|}{ Total sugars \% } & \multicolumn{3}{c|}{ Reducing sugar \% } & \multicolumn{3}{c|}{ Non-reducing sugars \% } \\
\cline { 2 - 10 } & $\mathbf{2 0 1 4}$ & $\mathbf{2 0 1 5}$ & Mean & $\mathbf{2 0 1 4}$ & $\mathbf{2 0 1 5}$ & Mean & $\mathbf{2 0 1 4}$ & $\mathbf{2 0 1 5}$ & Mean \\
\hline GA $_{\mathbf{3}} \mathbf{5}+\mathbf{2 0}+\mathbf{3 0} \mathbf{~ p p m}$ & 19.84 & 18.38 & 19.11 & 19.23 & 17.79 & 18.51 & 0.60 & 0.59 & 0.59 \\
\hline Thinning & 22.04 & 19.64 & 20.84 & 21.53 & 19.05 & 20.29 & 0.51 & 0.59 & 0.55 \\
\hline GA $_{3} \mathbf{5} \mathbf{~ p p m}+$ Thinning & 22.19 & 19.33 & 20.76 & 21.61 & 18.86 & 20.24 & 0.57 & 0.48 & 0.52 \\
\hline Control & 21.95 & 19.11 & 20.53 & 21.35 & 18.42 & 19.89 & 0.60 & 0.69 & 0.64 \\
\hline L.S.D. 5\% & 01.04 & NS & 0.78 & 01.01 & NS & 0.76 & NS & 0.18 & 0.12 \\
\hline
\end{tabular}

The effect of $\mathrm{GA}_{3}$ to increase the berry size, yield and decrease the cluster compactness by increasing the cluster length has been reported in many papers. Hopping (1975) found that $\mathrm{GA}_{3}$ at 5-40 ppm decreased cluster compactness, however, yield/vine, sugar and acid contents were not affected. On Red Roomy grape cultivar, $\mathrm{GA}_{3}$ increased cluster length (Abd-El-bar and El-Hagab, 1978) and increased yield weight, berry and cluster weight while it decreased berry quality (Hussein et al., 1986). Same results were found on Orland Seedless grape (Halbrooks and Mortensen, 1987), on Perlettegrape (Hassan et al., 1988), Dokoozlian and Peacock (2001) on Crimson Seedless grape cultivar and Rizk-Alla et al. (2011) on Black Monukka grape cultivar.

On the other hand, the results of the current study came on line with these reported by Ahmed (1988), Mahmoud (1989a and b), Shaaban et al. (1989), Mansour (1994), and Abd-El-Ghany (2000) found that treated Thompson Seedless grape with $\mathrm{GA}_{3}$ increased yield and cluster weight while it decreased $\mathrm{TSS} \%$, sugars and increased the total acidity.

Cluster and berry thinning are a common practice performed on many table grape cultivars to spare more carbohydrates for the remaining berries which surely reflected on advancing the berry ripening and improving its quality. Investigators 
(Abd El-Galil and El-Wasfy, 2003; Mohsen, 2005; Zhao et al., 2006; Abd El-Wahab, 2006; Gerges, 2007; Mohamed and Shaaban, 2008; Damota et al., 2010; Santesteban et al. (2011); Özer et al. 2012; and Bogicevic et al., 2015) found that cluster or berry thinning increased cluster weight, berry weight and size and improved berry quality.

\section{References}

Abd El-Galil, H.A. and M.M. El-Wasfy (2003). Effect of some cultural practices on King's Ruby grapevines production under Assiut conditions. Assiut J. Agric. Sci., Vol. 34 (6): 207-217.

Abd El-Ghany, A.A. (2000). Effect of shoot topping, paclobotrazol and gibberellic acid application on fruit quality of Thompson Seedless grapevines. Assiut Journal of Agricultural Sciences, Vol. 31 (2): 49-57.

Abd El-Wahab, M.A. (2006). An attempt towards improving bunch quality through berry thinning and trunk girdling treatments in Black Monukka grape. J. Agric. Sci. Mansoura Univ., Vol. 31 (10): 6577-6593.

Abd-Elbar, M.Z. and M.H. El-Hagab (1978). The effect of some growth regulators on yield and fruit quality of Romi Red grapevine. Monoufeia J. Agric. Res., Vol. 1: 195-207.

Abdel-Hady, A.M. (1995). Response of Roomy Red grapevines to foliar sprays of urea and boron. Ph.D. Thesis, Fac. of Agric., Minia University.

Abu-Zahra, T.R. (2013). Effect of plant hormones application methods on fruit quality of "Superior Seedless" grape. Biosci., Biotech. Asia, Vol. 10 (2): 527-531.
Ahmed, F.F. (1988). Effect of gibberellic acid concentrations, number of application and time of spraying on yield and ripening of White Banaty seedless grapes (Vitisvinifera L.). Minia J. Agric. Res. \& Dev. Vol. 10, No. 2, 791-810.

Ali, A.H. (2000). Response of Flame Seedless grapevines to spraying with ascorbic acid and boron. Minia J. of Agric. Res. \& Develop. Vol. 20 (1): 159-174.

Association of Official Agricultural Chemists (1985). Official Methods of Analysis. A. O. A. C. $14^{\text {th }}$ Ed. Published by A. O. A. C., Washington, D. C., U S A.

Bogicevic, M.; V. Maras; M. Mugosa; V. Kodzulovic; J. Raicevic; S. Sucur and O. Failla (2015). The effect of early removal and cluster thinning treatments on berry growth and grape composition in cultivars Vranac and Cabernet Sauvignon. Chemical and Biological in Agriculture, 2 (13): 1-8.

Bybardi, A. and J.A. Shabanov (2010). Effect of the foliar application of magnesium and zinc on the yield and quality of three grape cultivars grown in the calcareous soils of Iran. Not. Sci. Biol., 2 (1): 8186.

Casanova, L.; R. Casanova; A. Moret and M. Agusti (2009). The application of gibberellic acid increases berry size of "Emperatriz" Seedless grape. Spanish Journal of Agricultural Research, 4: 919927.

Christensen, P. and F.L. Jensen (1978). Grapevine response to concentrate and to dilute application of two zinc compounds. Am. J. Enol. Vitic., Vol. 29 (3): 213-216.

Damota, R.V.; C.R. Desouza; C.P.C. Silva; G.D. Freitas; T.M. Shiga; E. Purgatto; F.M. Lajolo and M.A. Regina (2010). Biochemical 
and agronomical responses of grapevines to alteration of sourcesink ratio by cluster thinning and shoot trimming. Bragantia Campinas, Vol. 69 (1): 17-25.

Dokoozlian, N.K. and W.L. Peacock (2001). Gibberellic acid applied at bloom reduces fruit set and improves size of "Crimson Seedless" table grapes. Hort. Science, 36 (4): 706-709.

Ebrahiem, A.A. and B.R. Ahmed (2012). Effect of enriching boron and magnesium with vitamins on nutritional status and productivity of Ruby Seedless grapevines. Minia J. of Agric. Res. \& Develop., Vol. 32 (1): 149-164.

Er, F.; A. Akin and M. Kara (2011). The effect of different ways and dosages of boron application on black (Vitisvinifera L.) grapes yield and quality. Bulgarian Journal of Agricultural Science, 17 (4): $544-550$.

Er, F.; S. Gezgin and F. Bayrakli (2009). The effect of different zinc application methods and levels on yield and quality of Hesapali (Vitisvinifera L.) grape. Bulgarian Journal Agricultural Science, 15 (5): 410-416.

Farroq, M. and N.C. Hulmani (2000). Effect of growth regulators and boric acid and their stage of treatment on Bunc character of Arkavati Grape (Vitisvinifera L.). Karnatka J. Agric. Sci. Vol. 13 (4): 1049-1053.

Fawzi, M.I.F. and O.M. Hafez (2004). Effect of some growth regulators on yield and fruit quality of Perlette grapes. Annals Agric. Sci., Fac. Agric., Ain Shams Univ., Cairo, Egypt, Vol. 49 (2): 671686.

Gerges, V.H. (2007). Effect of crop load on Crimson Seedless grapes. J.
Agric. Sci., Mansoura Univ., Vol. 32 (10): 8503-8511.

Halbrooks, M.C. and J.A. Mortensen (1987). Influence of gibberellic acid and various management practices on berry seed and cluster development in "Orland Seedless" grape. Proc. Fla. State Hort. Sci., 100: 312-315.

Hassan, J.A.; A.A. Mohamad; Z.M. AlAmeeli and B.S. Hadi (1988). Effect of gibberelic acid yield and fruit quality of Perlette grape cultivar (Vitisvinifera L.). Annals Agric. Sci., Fac. Agric., Ain Shams Univ., Cairo, Egypt, 33 (1): 471-478.

Hopping, E. (1976). Effect of bloom applications gibberellic acid on yield and bunch rot of the wine grape "Seibel 5455". N.Z. Journal of Experimental Agriculture, Vol. 4: 103-107.

Hussein, A.A.M.; N.M.G. AbdelHameed; G.M. Nour and A.A. Moustafa (1986). Response of "Roumi Red" grapevines to applications of $\mathrm{CCC}$ and $\mathrm{GA}_{3}$. Annals Agric. Sci., Fac. Agric., Ain Shams Univ., Cairo, Egypt, 31 (1): 637-650.

Hussein, M.A.; F.M.A. Mostafa; A.Y. AbdEllah and S.M. Mohamed (1998). Studies on physiological effect of gibberellic acid and kinetin application on Banaty (Thompson Seedless) grapes during storage. Assiut Journal of Agricultural Sciences, Vol. 29 (4): 31-41.

Kamal, U (2006). Extending marketing window of Thompson Seedless grapes by synthetic cytokinin and napththalene acetic acid preharvest spray treatments and cold storage. J. Agric. Res. Tanta Univ., 32 (3): 662-672.

Krizsics, A.C. and L. Diofasi (2007). Investigations into the correlation 
between boron concentration and yield characteristics with the grape cultivar "Cabernet Sauvignon" on different rootstocks. MitteilungenKlosterneuburg, 57: 213-223.

Mahmoud, H.M. (1989 a). Effect of some growth regulators on fruit characteristics and maturation of White Banaty Seedless grapes. Assiut Journal of Agricultural Sciences, Vol. 20 (4): 11-19.

Mahmoud, H.M. (1989 b). The effect of $\mathrm{GA}_{3}$ and $\mathrm{B}-9$ vegetative and fruiting in White Banaty Seedless grapevines. Assiut Journal of Agricultural Sciences, Vol. 30 (3): 61-69.

Mansour, A.E.M. (1994). Application of gibberellic acid and cycocel on berries development and productivity of Thompson Seedless grapevines. Minia J. Agric. Res. \& Dev. Vol. 16: 323-334.

Mohamed, A.K.A. and A.M. El-Sese (2004). Effect of some chemical compounds and growth regulators on regularity of bud break, flowering and fruiting of Red Roomy grapevine (Vitisvinifera L.). Assiut Journal of Agricultural Science, Vol. 35 (2): 165-181.

Mohamed, A.K.A. and M.M. Shaaban (2008). Improvements in berry quality of Ruby Seedless and Beauty Seedless grapes. Assiut J. Agric. Sci., Vol. 39 (5): 81-91.

Mohsen, F.S. (2005). Minimizing shot berries level and improving quality of Superior Seedless table grapes using boron and $\mathrm{GA}_{3}$. Int. J. Curr. Res. Biosci. Plant Biol., 2 (6): 107-114.

Nikkhah, R.; H. Nafar; S. Rastgoo and M. Dorostkar (2013). Effect of foliar application of boron and zinc on qualitative and quantitative fruit characteristics of grape- vine (Vitisvinifera L.). Int. J. Agri. Crop Sci., Vol. 6 (9): 485-492.

Oinoue, Y. (1938). Effect of boron on the setting of berries of grape Muscat of Alexandria. Journal of the Horticultural Association of Japan Vol. IX: 141-143.

Omar, A.H. and V.H. Girgis (2005). Some treatments affecting fruit quality of Crimson Seedless Grapevines. J. Agric. Sci. Mansoura Univ., 30 (8): 4665-4673.

Ozer, C.; A.S. Yasain; O. Ergonul and S. Aydin (2012). The effect of berry thinning and gibberellin of RecelUzumu Table grapes. Pak. J. Agric. Sci. Vol. 49 (2): 105-112.

Prabau, C.P. and P. Singaram (2002). Alleviation of zone constraints through foliar application of zinc and boron for grapes. Prabu \& Singaram, 22: 1262-1265.

Radwan, M.A. (1999). The effect of boron, girdling and pinching on vegetative growth and fruiting in Red Roomy grapevines. M.Sc. Thesis, Fac. Agric., Assiut University, pp. 118.

RizkAlla, M.S.; A.M.A. and F.O.M. (2011). Application of $\mathrm{GA}_{3}$ and NAA as a means for improving yield, fruit quality and storability of Black Monukka grape cv. Nature and Science, 9 (1): 1-19.

Santesteban, L.G.; C. Miranda and J.B. Royo (2011). Thinning intensity and water regime affect the impact cluster thinning has on grape quality. Vitis, 50 (4): 159-165.

Shaaban, E.A.; M.M. Tanahy and M.M. Nageib (1989). Effect of $\mathrm{GA}_{3}$ and Vapor-Gard on yield and fruit quality of "Thompson Seedless" grapevine. Assiut Journal of Agricultural Sciences, Vol. 20 (1): 313.

Snedecor, G.W. and W. G. Cochran (1972). Statistical Methods, Iowa State University, Ames, U S A. 
Song, C.Z.; M.YT. Liu; J.F. Meng; M. Chi; Z.M. Xi and Z.W. Zhang (2015). Promoting effect of foliage sprayed zinc sulfate on accumulation of sugar and phenolics in berries of Vitisvinifera cv. Merlot growing on zinc deficient soil. Molecules, 20: 2436-2554.

Subramoniam, S.R.; K. Subbiah; V.P. Duraisami and U. Surendran (2006). Micronutrients and $\mathrm{Zn}$ solubilizing bacteria on yield and quality of grape variety Thompson Seedless. International Journal of Soil Sciences, 1 (1): 1-7.

Zhao, X.J.; X. Wang; B. Liu; J.L.; Y.X. Sun and H.R. Shu (2006). Effect of cluster thinning on catechins in berries of Vitisvinifera cv. Cabernet Sauvignon. Vitis Vol. 45 (2): 103-104. 
تحسين المحصول والجودة في صنفي العنب الرومي الأحمر والطومسون عديم البذور

أيمن كمال أحمد محمد، فاطمة الزهراء محمد عبدالله جودة، رشاد عبد الوهاب ابراهيم

وياسمين محمد أحمد مدكور

قسم الفاكهه - كلية الزر اعة - جامعة اسيوط

الملخص

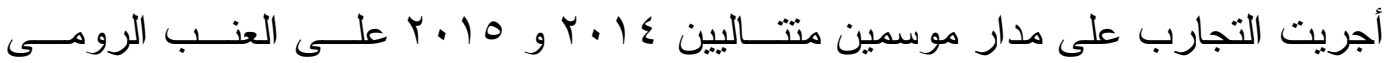
الاحمر و الطومسون عديم البذور المزروع في مزرعة أبحاث الفاكهة - كلية الزر اعة عاعة - جامعان

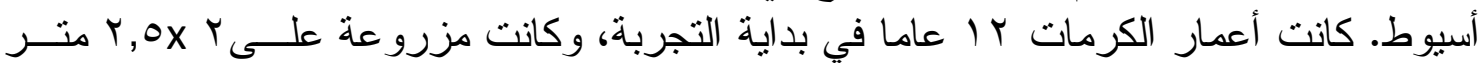

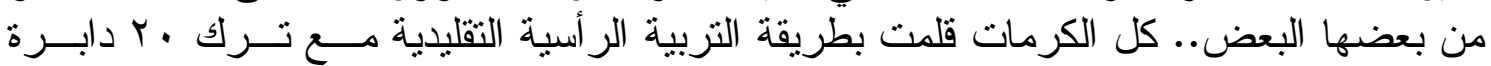
ثمرية و ك عيون على كل دابرة للعنب الرومى الاحمر و 0 عيون للطومسون عديم بذور.

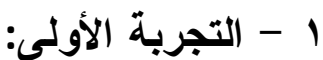

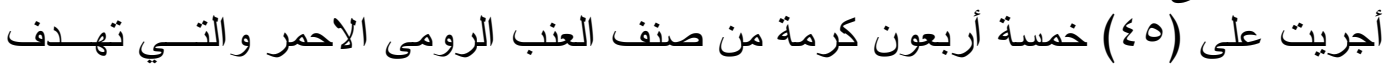

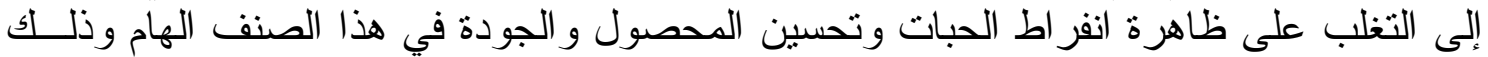

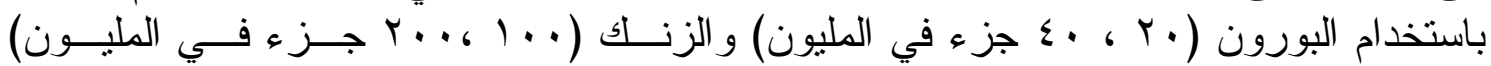

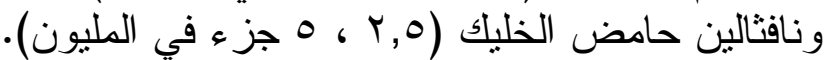

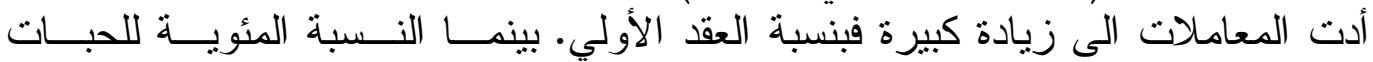

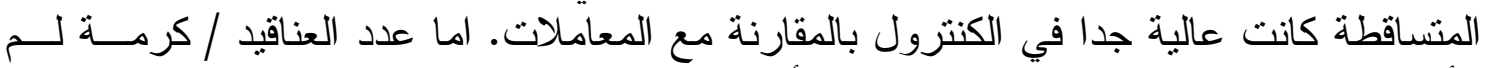

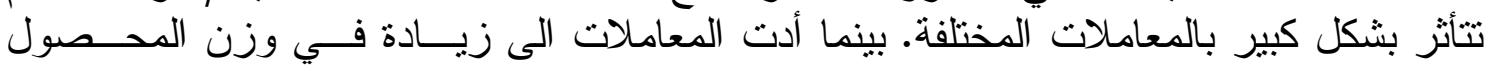

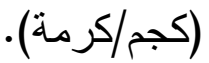
لم تكن هناك اختلافات معنوية بين المعاملات من ناحية عرض العنقود. اما ارتات ارتفاع العنقود

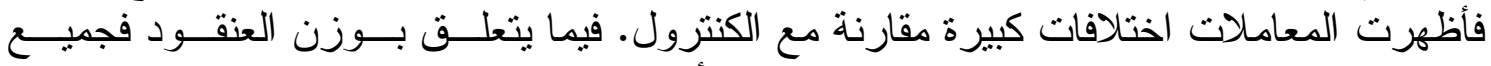

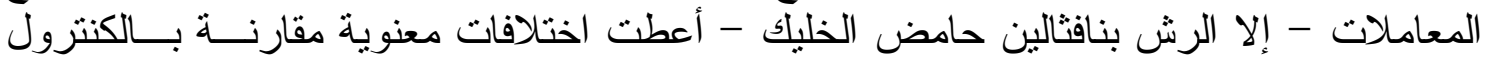

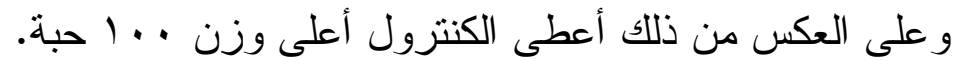

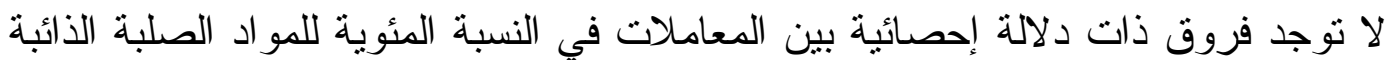
الكلية خلال الموسمين. إن أعلى نسبة حموضة كانت مع المعاملة بنفتالين حامض الخليك بتركيز

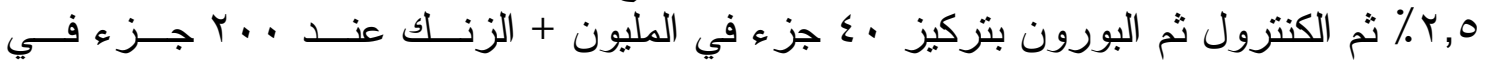

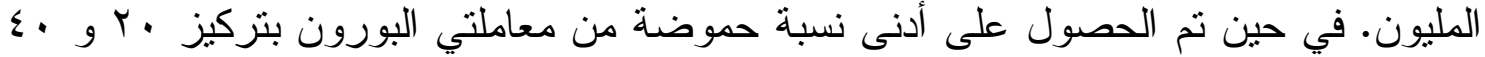

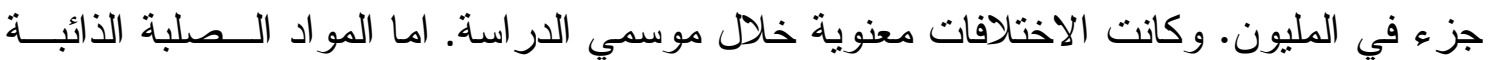

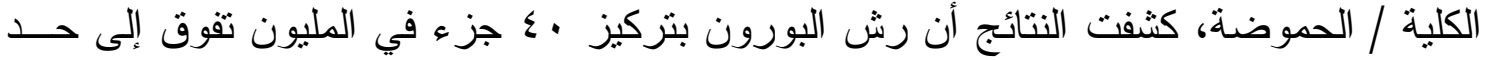

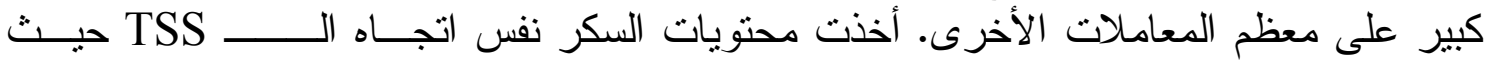

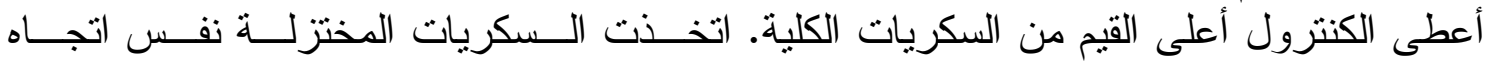
السكريات الكلية حيث تفوقت معاملة الكنترول على جميع الفئ المعاملات الأخرى.

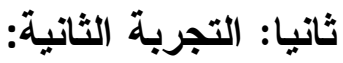

وكان الهدف من هذه التجربة هو الحد من اكتتاز العنقود وذلك بالرش بحامض الجبريليك

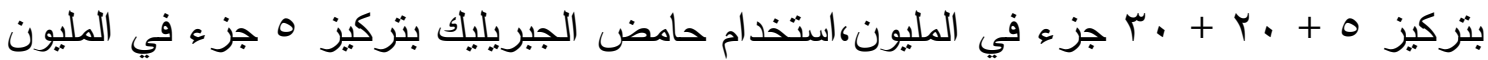

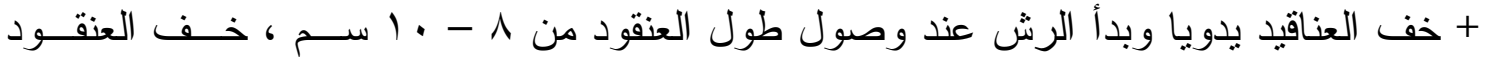

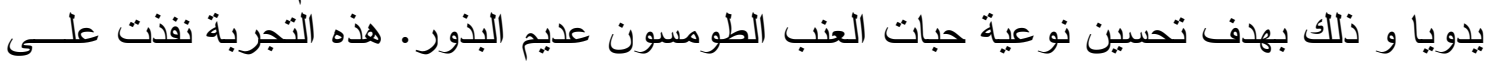




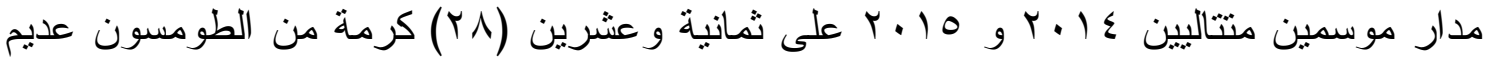

لا نوجد فروق ذات دلالة إحصائية بين المعاملات على عدد العناقيد/ الكرمة. بينمــا وزن

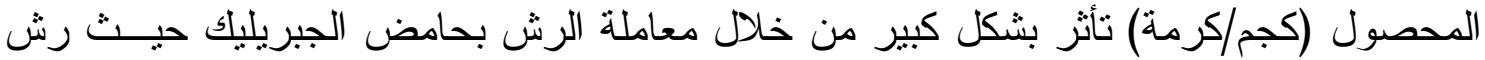

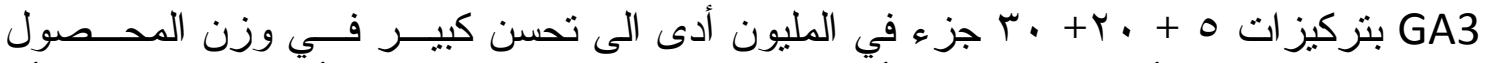

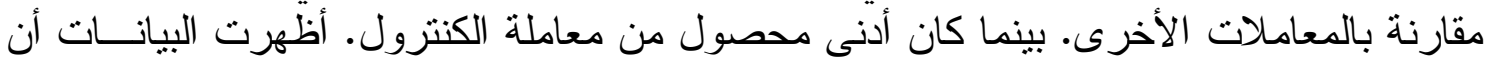

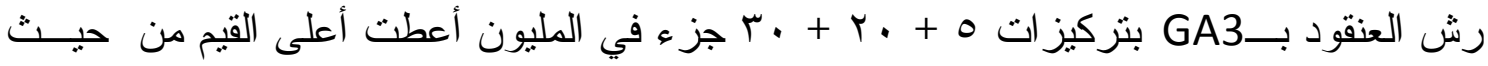

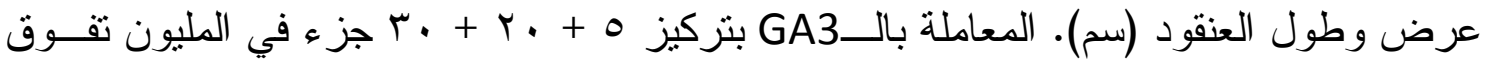

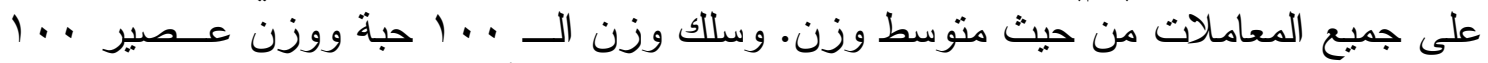

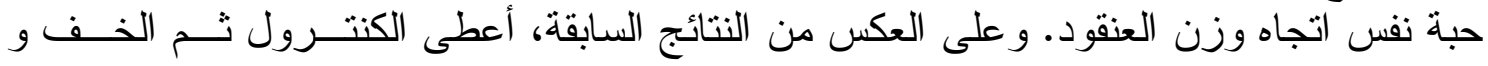

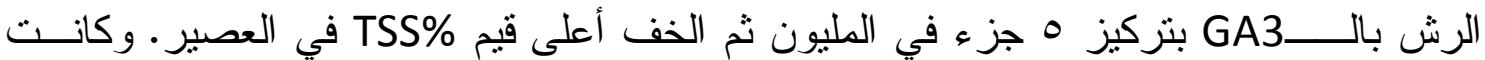

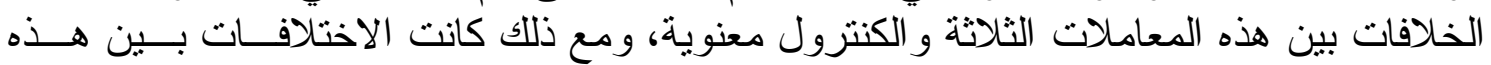

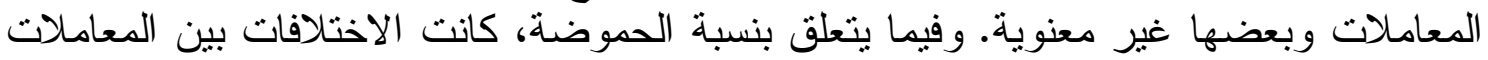

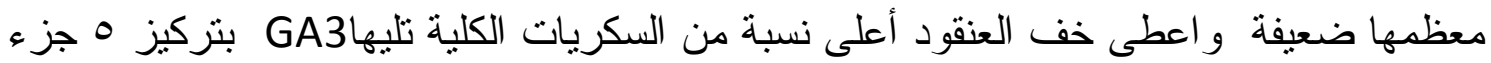

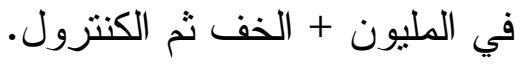

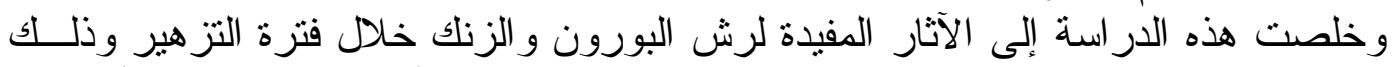

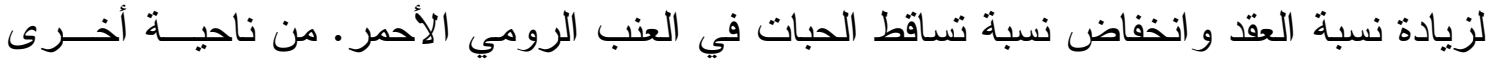

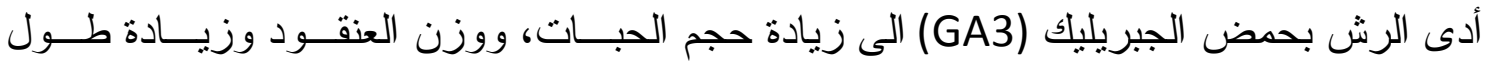
العنقود الطومسون عديم البذور حيث يعاني هذا الصنف من اكتتاز العنقود. كذللك يمكن استخدام الخف لزيادة وزن العنقود و الحبات وتحسين الجودة. 